\title{
REPRESENTASI SEKSUALITAS DALAM NOVEL SAMAN KARYA AYU UTAMI
}

\author{
Rina Patriana Chairiyani \\ Jurusan Psikologi, Faculty of Humanities, BINUS University \\ Jln. Kemanggisan Ilir III No. 45, Kemanggisan-Palmerah, Jakarta Barat 11480 \\ patriana_rina@yahoo.com
}

\begin{abstract}
Saman is a literature written by Ayu Utami. Showing a representation of a female counterpart ideology that differs from what has already been made in heterosexual and patriarchal society. The community considers sex is taboo to talk openly. In this novel it is represented openly. Women are no longer in a weak position, and have choices. In this paper, research methodology used is qualitative method.
\end{abstract}

Keywords: representation, sexuality, Saman novel

\begin{abstract}
ABSTRAK
Saman adalah karya sastra yang ditulis oleh Ayu Utami. Menampilkan representasi tandingan yang menampilkan ideologi perempuan yang berbeda dengan apa yang telah dibuat masyarakat heteroseksual dan patriarkal. Masyarakat selama ini menabukan seks untuk dibicarakan secara terbuka, dalam novel ini direpresentasikan secara terbuka. Perempuan tidak lagi berada dalam posisi yang lemah dan tidak memliki pilihan. Adapun metode penelitian yang dipakai adalah metode penelitian kualitiatif.
\end{abstract}

Kata kunci: representasi, seksualitas, novel Saman 


\section{PENDAHULUAN}

Sastra merupakan suatu bentuk hasil pekerjaan seni kreatif yang objeknya adalah manusia dengan segala kehidupannya dan menggunakan bahasa sebagai mediumnya. Objek sastra adalah persoalan kehidupan yang terjadi dalam kehidupan manusia yang erat hubungannya dengan sosial budaya, pendidikan, agama, psikologi, dan kesenian (Semi, 1989: 2). Bagi seorang pengarang yang memiliki kepekaan yang tinggi terhadap lingkungan akan menjadi bahan renungan dan pemikiran. Dari penghayatan dan perenungan tersebut ditambah dengan daya imajinasi pengarang, terciptalah sebuah karya sastra yang dituangkan dalam media tulis.

Sastra juga merupakan alat untuk mengungkapkan suatu kenyataan yang ditemukan dalam masyarakat. Karya sastra khususnya novel, lahir oleh keinginan dasar manusia untuk mengungkapkan diri dan menaruh minat pada dunia realitas tempat hidupnya dan pada dunia angan-angan yang dikhayalkan sebagai dunia nyata. Di dalamnya ditampilkan gambaran kehidupan, sedangkan kehidupan itu sendiri adalah suatu kenyataan sosial yang mencakup hubungan antarmasyarakat dan antarperistiwa yang terjadi di dalam batin seseorang.

Kehadiran karya sastra mempunyai arti tersendiri bagi manusia karena pada hakikatnya persoalan-persoalan yang diungkapkan oleh karya sastra adalah persoalan-persoalan manusia. Persoalan tersebut tidak saja persoalan mengenai diri sendiri, tetapi juga persoalan yang ada di sekitar hidup dan kehidupannya. Nilai-nilai yang disajikan dalam karya sastra membuka batin pembaca dalam menemukan pengalaman-pengalaman baru. Melalui karya sastra diharapkan terpeliharanya sikap kritis, kemampuan menolak, melakukan protes terhadap perasaan, pikiran dan tingkah laku yang ditampilkan dalam karya sastra tersebut.

Karya sastra pada hakikatnya terbagi atas dua golongan yaitu prosa fiksi, drama, dan puisi. Fiksi sering juga disebut cerita rekaan yang dihasilkan oleh pengarang yang didasari oleh pandangan, tafsiran, penilaian tentang persoalan hidup dan kehidupan manusia yang ada di masyarakat. Oleh karena itu, karya sastra dipandang sebagai gejala sosial suatu masyarakat karena keterkaitan langsung dengan kehidupan yang terdapat dalam masyarkat pada zaman itu. Sebuah sastra dapat mewakili masyarakat suatu zaman dan dapat dijadikan acuan oleh manusia pada masa yang akan datang untuk mempelajari sejarah manusia dan kehidupannya.

\section{Novel}

Novel adalah bentuk karya sastra yang imajinatif dan bentuk sastra yang paling popular di dunia. Dewasa ini bentuk sastra ini lebih banyak beredar. Novel semakin digemari oleh penikmat sastra. Dalam arti luas novel adalah cerita berbentuk prosa dalam ukuran yang luas. Luas yang dimaksud adalah cerita dengan plot yang kompleks, karakter yang banyak, suasana cerita yang beragam dan setting cerita yang beragam pula.

Sebagai bahan dasarnya, novel menggunakan cerita yang kemudian disampaikan kepada pembaca. Menurut Foster, cerita adalah pemisahan kejadian dalam waktu dan merupakan basis sebuah novel (Foster, 1970: 37). Tanpa adanya cerita, maka seorang pengarang novel akan sia-sia saja berkomunikasi dengan pembaca. Jadi, seseorang tidak mungkin menulis novel dengan mengabaikan unsur cerita, karena cerita merupakan hakikat novel (Pamusuk, 1991:12).

Dalam novel disampaikan cerita, ide, amanat atau maksudnya diperlukan pertolongan katakata. Seorang novelis hanya bisa menyampaikan cerita dan amanatnya dengan kata-kata dan juga membangun alur, penokohan, latar, dan suasana dengan bantuan kata-kata. Kata-kata menempati kedudukan penting dalam novel (Pamusuk, 1991:16). 
Berdasarkan uraian di atas, novel juga dapat dikatakan sebagai media cerita yang menggunakan bahasa, dan dapat disimpulkan pula bahwa kata-kata dalam novel tidak sekadar menyampaikan ide-ide. Sebuah novel yang baik tidak hanya berisi cerita namun juga berusaha untuk menyampaikan sebuah kata-kata. Adapun syarat utama sebuah novel haruslah menarik, menghibur dan mendatangkan rasa puas setelah orang selesai membacanya.

\section{Representasi}

Terminologi representasi sudah dikenal sejak zaman Aristoteles dan dijelaskan secara sederhana sebagai tindakan yang menggantikan sesuatu yang tidak dapat terjadi atau tidak mampu menghadirkannya sendiri (Childers and Hentzi, 1995:261). Sedangkan menurut Judith Butler dalam bukunya Gender Trouble, representasi dalam proses politiknya mengembangkan kemungkinan dan legitimasi identitas seksual sebagai subjek. Pihak yang menguasai (heteroseksual, laki-laki) dan pihak yang dikuasai (perempuan) saling berperang (Butler, 1990). Dalam representasi penguasa berusaha menjatuhkan yang dikuasai dan sebaliknya yang dikuasai membuat perlawanan atau subversi sehingga kekuasaan sangat penting dalam jalinan hubungan ini. Menurut Stuart Hall, representasi dapat dilihat melalui tiga pendekatan. Pendekatan reflektif, pendekatan intensional, pendekatan konstruksionis. Pendekatan reflektif melihat representasi sebagai penyampaian makna yang pemikirannya terletak pada objek, orang, idea atau kejadian yang ada di alam nyata. Pendekatan intensional melihat representasi sebagai suatu cara menyampaikan hal-hal khusus atau unik dalam melihat dunia. Sedangkan pendekatan konstruksionis memandang representasi sebagai pembangun makna menggunakan sistem representasional (Hall, 2003:24-25). Jadi, dapat dikatakan representasi adalah penggambaran atau bahkan perlawanan terhadap sesuatu yang tidak dapat dilakukan yang ada di dunia nyata.

\section{Seksualitas}

Menurut Rathus seksualitas adalah cara kita memandang dan mengekspresikan diri kita sebagai makhluk seksual (Rathus, 2009: 3). Menurut Judith Butler, seksualitas bukanlah sekedar konstruksi sosial tetapi semacam performance dengan segala atribut yang dikenakan (Butler,1990). Atribut ini semacam label yang diberikan oleh masyarakat. Oleh karena itu, ia bersifat cair dan tidak tetap. Atribut yang ditetapkan oleh masyarakat dominan di suatu tempat dan waktu berbeda dengan masyarakat dominan di tempat dan waktu yang berbeda.

Selama ini, seksualitas umumnya menjadi subjek yang dianggap tabu untuk dibicarakan secara terbuka dalam masyarakat, apalagi jika dituangkan di dalam sebuah novel. Ayu Utami mencoba mendobrak paradigma tersebut dengan memunculkan karyanya yang berjudul Saman. Saman menggambarkan kegelisahan empat orang tokoh perempuan dalam kehidupan seksualitasnya. Novel ini diciptakan Ayu Utami berisi gambaran kehidupan manusia dan lingkungan dengan menampilkan jiwa zaman yang terjadi pada saat itu. Dengan membaca novel ini, kita dapat melihat bahwa seksualitas yang selama ini dianggap tabu dan menjadi magma terpendam pada masyarakat yang sarat dengan konvensi-konvensi budaya, digambarkan secara terbuka oleh Ayu Utami.

Novel ini sendiri berhasil memenangkan Sayembara Roman Dewan Kesenian Jakarta 1998. Setelah membaca novel ini penulis tertarik untuk melakukan penelitian terhadap novel tersebut. Penulis bermaksud mendeskripsikan cara pengarang dalam mengungkapkan representasi seksualitas. 


\section{METODE PENELITIAN}

Penelitian ini adalah penelitian kualitatif deskriptif dengan metode analisis isi. Metode penelitian ini bertujuan membuat deskripsi, gambaran, atau lukisan secara sistematis, faktual, akurat mengenai fakta, sifat serta hubungan antara kenyataan yang diteliti kemudian disusul dengan analisis. Instrumen penelitian ini adalah peneliti sendiri, yaitu dengan membaca dan memahami serta mencatat isi novel Saman kemudian menginventarisasi kalimat-kalimat yang menggambarkan representasi seksual. Selanjutnya, digunakan untuk menafsirkan dan menganalisis representasi seksual yang terdapat dalam novel tersebut. Analisis dilakukan dengan menyusun dan menggambarkan bagaimana teks-teks sastra dan nonsastra memproduksi representasi seksualitas dalam cerita tersebut. Karena penelitian ini menampilkan representasi dari cerita tersebut maka diperlukan teori sastra queer theory dan feminism. Teori tersebut mempunyai cara kerja dekonstruksi yang menampilkan bangunan seksualitas tandingan sebagai bangunan alternatif untuk menumbangkan bangunan yang sudah dibuat oleh masyarakat Indonesia dalam novel Saman.

\section{HASIL DAN PEMBAHASAN}

Laila Gagarina (Laila), Yasmin Moningka (Yasmin), Cokorda Gita Magaresa (Cok), dan Shakuntala (Tala) adalah para tokoh utama perempuan dalam novel Saman. Kehidupan seksual mereka dibahas secara rinci dan jelas oleh Ayu Utami. Gaya kehidupan seksual mereka tidak jamak dilakukan oleh perempuan Indonesia walaupun mungkin dapat ditemukan di kota-kota besar. Masalah ini belum dibicarakan secara terang-terangan dalam masyarakat.

Para tokoh utama perempuan tersebut menjalani kehidupan seksual yang bebas dan tidak menganggapnya sebagai sesuatu yang sakral. Mereka tidak memedulikan lembaga perkawinan. Mereka adalah perempuan-perempuan yang memiliki kegelisahan dalam bermasyarakat, terutama kegelisahan seksual. Kegelisahan seksual itu melekat pada Representasi Seksualitas dalam Saman.

\section{Perempuan Sebagai Identitas Seksual}

Salah seorang tokoh perempuan dalam Saman, yakni Laila, adalah seorang fotografer yang jatuh cinta pada Sihar Situmorang, seorang insinyur perminyakan yang bekerja di rig. Sihar sudah mempunyai istri. Meskipun Laila tahu bahwa Sihar sudah beristri, namun hasratnya untuk bercumbu (petting) dengannya terus membayangi. Bahkan ketika Sihar berangkat ke Amerika Serikat (New York), Laila berusaha melakukan hubungan seksual itu. Namun, upaya Laila untuk merebut hati Sihar menemui kegagalan, karena Sihar berangkat ke New York bersama Istrinya. Bagi dia hubungan seksual adalah suatu permainan saja dan sesuatu yang dapat dilakukan siapapun untuk menikmati kesenangan ini tanpa harus mengingat adanya aturan dan pandangan masyarakat terhadap hubungan seksual ini. Hubungan ini menunjukkan bahwa lembaga perkawinan tidak dapat mengatur perilaku ketjuga menunjukkan dapat mempermainkan laki-laki sebagai Yang Menguasai dalam kehidupan masyarakat selama ini. Bahwa, peraturan yang dibuat patriarki tentang perkawinan telah dilanggar oleh Lalia.

Tokoh utama perempuan lain yang juga mengalami kegelisahan seksual adalah Yasmin, seorang pengacara yang menikah dengan Lukas Hadi Prasetyo. Namun, Yasmin berselingkuh dengan seorang pastor, Romo Wis, panggilan Athanasius Wisanggeni, yang kemudian berganti nama menjadi Saman saat berada dalam status buronan. Mereka melakukan hubungan seksual saat Yasmin dan Saman berada di Pekanbaru, ketika Saman hendak dilarikan ke Amerika. Hubungan Yasmin dengan Romo Wis (Saman) itu berlanjut melalui surat elektronika (e-mail) yang mampu membuat Yasmin orgasme membaca surat-surat Saman. 
Sementara Cok adalah tokoh utama perempuan yang sejak duduk di bangku SMA (kini SMU) sudah menganut aliran freesex. Ia pernah dipindahkan ke SMU di Bali gara-gara orangtuanya menemukan kondom di tas sekolahnya, Di Bali, justru pertualangan seksnya semakin menjadi-jadi hingga menginjak dewasa.

Dalam Saman, ketidakpedulian terhadap lembaga perkawinan dan kegelisahan seksual yang dialami oleh para tokoh perempuannya merupakan pendobrakan atas nilai-nilai patriarkal yang ada dalam masyarakat kita atau falosentrisme. Mereka tidak lagi memikirkan norma sosial yang berlaku bahkan berani melawan tabu yang selama ini menjadi magma terpendam pada masyarakat yang sarat dengan konvensi-konvensi budaya. Pendobrakan ini seiring dengan tumbuhnya ide-ide persamaan hak antara laki-laki dan perempuan di Indonesia.

Hal tersebut sejalan dengan apa yang dikemukakan oleh Butler bahwa gender dan seksualitas bukan hanya konstruksi sosial tetapi semacam performance dengan segala atribut yang dikenakan. Atribut ini semacam label yang diberikan oleh masyarakat. Oleh karena itu, ia bersifat cair dan tidak tetap. Atribut yang ditetapkan suatu masyarakat dominan di suatu tempat dan waktu yang lain. Hal ini terlihat pada halaman 28, dialog antara Laila dengan Sihar:

Barangkali saya letih dengan segala yang menghalangi hubungan kami di Indonesia. Capek dengan nilai-nilai yang kadang terasa seperti terror. Saya ingin pergi dari itu semua dan membiarkan hal-hal yang kami inginkan terjadi. Mendobrak yang selama ini menyekat hubungan saya dengan Sihar, Barangkali. (Utami, 2006)

Dalam novel Saman, perbedaan atmosfer itu digambarkan ketika Laila berada di New York untuk menemui Sihar. Di New York, Laila merasakan atmosfer yang lain, bahwa di kota itu orangorang tidak memedulikan apakah seseorang masih perawan atau tidak, apakah seorang perempuan menikah atau tidak. Berbeda ketika di Indonesia, Laila selalu merasa dibayang-bayangi oleh seluruh norma sosial yang mengukungnya. Namun, di New York, Laila akhirnya merasa kecewa karena ternyata Sihar tidak menepati janjinya untuk bertemu. Padahal dia merencanakan jika bertemu dengan Sihar, dia akan melakukan hubungan seks yang selama ini di Indonesia belum pernah dia lakukan. Di negeri yang bisa jadi dianggap sebagai media pelarian ketertekanan seksual sang tokoh pada kultur yang membesarkannya. Mungkin karena Amerika-lah yang dianggap negeri yang mampu mewakili representasi eksistensi seksual perempuan. Di mana industri seksnya melimpah, bahkan ada jenis komoditi yang menjanjikan seks-seks ilegal, bahkan abnormal semisal bondage sadomasochis (seks sadis), voyeurism (mengintip), amateur, mature dan older (orang bangkotan), sampai surveillance sex (dokumentasi seks orang-orang biasa) (Sugiarti dalam http://www.sinarharapan.co.id/hiburan/budaya/2004/04/3/bud02.html).

Sedangkan sebagaimana yang kita ketahui Indonesia adalah salah satu negara yang sebagian besar masyarakatnya menganut sistem patrilineal. Masyarakat terutama yang menganut sistem patrilenial membuat sebuah bangunan ideologi perempuan, bahwa perempuan dikonstruksi sebagai yang lemah dan harus mengalah. Yang lemah dan harus mengalah ini dialami perempuan dalam berbagai aspek. Bahkan dalam pemakaian namapun perempuan diharuskan mengalah kepada laki-laki. Hal ini dapat dilihat pada halaman 37, dialog antara Shakuntala dengan petugas di kedutaan Belanda yang menanyakan nama keluarga.

\footnotetext{
"Nama saya Shakuntala. Orang Jawa tidak punya nama keluarga."

"Anda memiliki ayah,bukan?”

"Alangkah indahnya kalau tidak punya."

“Gunakan nama ayahmu,” kata wanita di loket itu.

"Dan mengapa saya harus memakainya?"

"Formulir ini harus diisi."
} 
Aku pun marah. "Nyonya, Anda beragama Kristen bukan? Saya tidak, tetapi saya belajar dari sekolah Katolik. Yesus tidak mempunyai ayah. Kenapa orang harus memakai nama ayah?"

Lalu aku tidak jadi memohon visa. Kenapa ayahku harus tetap memiliki sebagian dariku? Tapi hari-hari ini semakin banyak orang Jawa tiru-tiru Belanda. Suami istri memberi nama si bapak pada bayi mereka sambil menduga anaknya bahagia atau beruntung karena dilahirkan. Alangkah melesetnya. Alangkah naif.

Kenapa pula aku harus memakai nama ayahku? Bagaimana dengan nama ibuku? (Utami, 2006: 137)

Lalu aku melobi mereka agar tidak memaksaku mengenakan nama ayahku dalam dokumendokumen, sebab kami tak punya konsep itu. Dan kukira tidak perlu. "Tapi tak mungkin orang cuma mempunyai satu kata,"kata mereka. Atau, barangkali aku ini bukan orang? Lalu aku terpaksa kompromi, sebab jangan-jangan aku memang bukan orang padahal aku betul-betul ingin melihat negeri mereka. First name: Shakun. Family name: Tala (Utami, 2006: 138).

Shakuntala yang membenci bapaknya, tidak menginginkan nama bapaknya dibelakang namanya. Namun, aturan keumuman menerapkan penggunaan nama bapak sebagai nama keluarga. Terutama sekali dalam penulisan dokumen-dokumen legal dalam pemerintahan. Ketika seseorang tidak mengikuti aturan umum ini, maka dianggap sebagai sesuatu yang aneh. Perempuan, dalam hal ini tokoh Shakuntala, ingin menunjukkan identitas dirinya bukan yang lainnya.

Penolakan pemakaian nama bapak yang dilakukan Shakuntala menunjukkan pemberontakannya akan aturan dalam sistem patriarkal. Dalam sistem ini perempuan adalah milik laki-laki dengan memakai nama ayahnya. Sistem ini tidak memberikan tempat bagi perempuan untuk memiliki anaknya - dengan tidak memakai nama ibunya - bahkan untuk memiliki dirinya sendiri. Oleh karena itu, Shakuntala merasa dia tidak hadir atau ada. Dia akan selalu "dimiliki" dan dalam bayang-bayang bapaknya dengan memakai nama bapaknya. Dia ingin menunjukkan kerinduannya akan "keindahan" hidup apabila dia hadir sebagai dirinya sendiri. Kebencian kepada ayahnya adalah kekecewaan dan ketidakberdayaan menghadapi dan menentang sistem patriarkal. Konstruksi sosial ini telah membuat perempuan menderita dan tidak dapat mempunyai identitas seksualnya.

Bentuk lain konstruksi sosial yang ada dalam masyarakat, bahwa penilaian harga diri perempuan melalui keutuhan selaput daranya ketika dia menikah. Jika keutuhan itu terkoyak sebelum adanya pernikahan, maka perempuan itu dianggap tidak memiliki harga. Selaput dara dijadikan alat legitimasi laki-laki untuk menempatkan perempuan pada tempat yang kotor apabila tidak memiliki selaput dara lagi sewaktu resmi menikah. Sedangkan laki-laki tidak pernah dipersoalkan apabila sudah pernah melakukan hubungan seksual sebelum menikah. Dalam novel ini konstruksi sosial digambarkan melalui percakapan di bawah ini:

Waktu mereka mulai mendengar bahwa aku suka sembunyi-sembunyi menemui seorang patung, piring, cangkir porselin boleh berwarna biru, hijau muda, maupun coklat. Tapi mereka tidak boleh retak, sebab orang-orang akan membuangnya ke tempat sampah, atau merekatkannya sebagai penghias kuburan. Ibuku berkata, aku tak akan retak selama aku memelihara keperawananku. Aku terheran, bagaimana kurawat sesuatu yang aku belum punya? Ia memberitahu bahwa di antara kedua kakiku, ada tiga lubang. Jangan pernah kau sentuh yang tengah, sebab disitulah ia tersimpan. Kemudian hari kutahu, dan aku agak kecewa, bahwa ternyata bukan cuma aku saja yang sebenarnya istimewa. Semua anak perempuan sama saja. Mereka mungkin saja teko, cawan, piring atau sendok sup, tetapi semuanya porselin. Sedangkan anak laki-laki? Mereka adalah gading: tak ada yang tak retak. Kelak, ketika dewasa kutahu mereka juga daging (Utami, 2006:124).

Tiba-tiba aku ingin teriak, tapi mulutku rapat-rapat karena aku tak ingin kembali bertengkar. Sebab menurutku yang curang lagi-lagi Tuhan: Dia menciptakan selaput dara, tapi tidak membikin selaput penis (Utami, 2006:149). 
Percakapan tersebut di atas juga menggambarkan kondisi ketidaksejajaran antara laki-laki dan perempuan. Pengkategorian seks melalui jenis kelamin, menurut Butler merupakan pengekangan atas kebebasan dan otonomi seseorang dalam hal ini terutama bagi seorang wanita dan kondisi tersebut sangat dinikmati oleh kaum pria (Butler, 1990: 19). Mereka mengontrol dan mengatur kehidupan dan posisi perempuan dalam masyarakat. Posisi ini sangat tidak menguntungkan kaum perempuan dan dirasa tidak adil. Apapun keadaan laki-laki, dia selalu menempati tempat yang lebih tinggi dan tidak dapat disalahkan. Kebaikan dan keindahan perempuan hanya dilihat dari keadaan fisiknya saja. Perempuan bagaikan sebuah benda, objek yang dapat dipermainkan, dan dinilai baik atau tidak menurut keadaan fisiknya. Hal ini dipertanyakan dan dituntut untuk diperbaiki oleh tokoh utama perempuan ini.

\section{Perempuan Sebagai Subjek Seksualitas}

Novel ini membicarakan seks dengan penuh keterbukaan yang provokatif, memprotes stereotip pasif perempuan, menolak falosentrisme pada umumnya, mengakui orientasi seksual yang plural. Terjadi pemberontakan atau pemutarbalikan terhadap relasi kekuasaan laki-perempuan yang normatif (Bandel, 2006: 111). Perilaku seksual yang diceritakan hampir sepenuhnya bertentangan dengan norma masyarakat (Indonesia), dalam arti bahwa yang diceritakan bukanlah hubungan heteroseksual yang disahkan oleh surat nikah. Laila jatuh cinta dengan seorang laki-laki yang sudah menikah, Shakuntala mempunyai kecenderungan biseksual, Yasmin mengkhianati suaminya dengan seorang pastor, dan Cok yang gemar berganti-ganti pasangan.

Pemberontakan tersebut dapat kita lihat pada ucapan tokoh Shakuntala berbicara mengenai ketidaksukaannya terhadap Sihar: "Laila bukanlah aku atau Cok, orang-orang dari jenis yang tidak peduli betul dengan pernikahan atau neraka, selain berpendapat bahwa keduanya adalah himpunan dan diantaranya ada irisan." (Utami, 2006: 127)

Selain itu, perempuan tidak lagi menjadi pihak yang pasif tetapi justru pihak yang aktif. Perempuan menjadi subjek bahkan dalam seksualitas. Seks adalah suatu aktivitas yang harus dinikmati oleh kedua belah pihak dan perempuan bisa saja menjadi subjek dalam aktivitas ini. Demikian pendapat tokoh Shakuntala terhadap Sihar: "Berhubungan seks dengannya pasti tidak imajinatif dan tak ada pembicaraan post-orgasme yang menyenangkan.” (Utami, 2006: 132)

Perempuan sebagai subjek dalam melakukan aktivitas seksual juga berarti bahwa ia berhak memiliki hasrat seksual, memperoleh kepuasan seksual yang sama dengan laki-laki, memilih pasangan, atau bahkan memutuskan atau menolak untuk melakukan aktivitas tersebut. Seperti yang terlihat dalam kutipan berikut ini:

Dan ia akan terharu. Ia akan mengecup dahi saya. Lembut, seperti orang yang menyayangi, yang tidak melulu birahi. Tapi akan saya katakan bahwa kali ini saya telah siap. Dan saya telah memilihnya sebagai lelaki yang pertama. Dia akan bertanya-tanya, kenapa dia. Saya akan menjawab, teman-teman saya bilang, pengalaman pertama jauh lebih indah dengan pria yang matang. Lelaki perawan, begitu kata mereka, tidak pernah tenang. Selalu gugup dan terburuburu. (Utami, 2006: 29)

Tokoh Yasmin yang digambarkan telah menikah melakukan perselingkuhan dengan Saman yang seorang romo, perselingkuhan ini sekaligus “memurtadkan” Saman. Sebagai seorang romo yang terikat kaul untuk hidup selibat, Saman seharusnya tidak boleh melakukan hubungan seksual, apalagi tanpa status yang jelas. Masyarakat Indonesia mempunyai bangunan ideologi tentang kehidupan seksual seorang biarawan. Dia digambarkan halus, sopan, tidak pernah berlaku tidak senonoh. Akan tetapi ideologi ini ditumbangkan secara luar biasa dalam Saman. Seseorang yang sudah terikat hubungan dalam perkawinan saja tidak boleh melakukan hubungan seksual dengan pasangan lain, apalagi Saman yang sudah terikat janji suci dengan Tuhan. Tentu saja juga tidak boleh melakukan 
hubungan seksual dengan seorang perempuan. Pemutarbalikan dan pemberontakan norma sekaligus penonjolan peran perempuan sebagai subjek dalam seksualitas kembali dapat dilihat dalam kutipan berikut ini:

\begin{abstract}
Saman,
Aku terkena aloerotisme. Bersetubuh dengan Lukas tetapi membayangkan kamu. Ia bertanyatanya, kenapa sekarang aku semakin sering minta lampu dimatikan. Sebab yang aku bayangkan adalah wajah kamu, tubuh kamu (Utami, 2006: 194)
\end{abstract}

Saman,

Orgasme dengan penis bukan sesuatu yang mutlak. Aku selalu orgasme jika membayangkan kamu. Aku orgasme karena keseluruhanmu (Utami, 2006: 195)

Saman,

Tahukah kamu, malam itu, malam itu yang aku inginkan adalah menjamah tubuhmu, dan menikmati wajahmu ketika ejakulasi. Aku ingin dating ke sana. Aku ajari kamu. Aku perkosa kamu (Utami, 2006: 195)

Kutipan tentang perkataan Yasmin di atas menunjukkan kesenangan dan kegairahan seksualnya dengan Saman. Selama ini laki-laki mengendalikan hubungan seksual dan permainan seksual dengan pasangannya. Perempuan hanyalah pemuas hasrat seksual laki-laki. Dia tidak boleh membantah, mengeluh, dan menolak. Bahkan perempuan tidak boleh, atau dianggap tabu mengungkapkan perasaannya tentang hubungan seksualnya. Ungkapan kenikmatan yang disuarakan Yasmin jelas sekali dianggap sangat tabu dan memalukan bagi masyarakat. Akan tetapi, hal ini menunjukkan bahwa Yasminlah yang mengendalikan permainan seksual dan menjadi subjek seksual karena menikmatinya. Bagi Yasmin, hubungan seksual adalah alami dan merupakan kebutuhan dasar manusia yang harus dinikmati. Serta bukanlah sesuatu yang bersifat sakral. Penguasaannya atas Saman menunjukkan kekuasaannya atas laki-laki bahkan laki-laki "suci" sekalipun yang tidak boleh disentuh oleh perempuan.

Perempuan sebagai subjek seksual juga ditunjukkan oleh tokoh utama perempuan yang lain, yaitu Cok. Dalam kutipan berikut ini terlihat bagaimana dia menikmati hubungan seksual.

Bagaimana dengan doimu yang di Jakarta? Gue enggak tahan pacaran jarak jauh, jawabnya, tapi gue juga enggak tahan enggak pacaran.

Namun, semakin lama semakin ruwet cerita yang ia tuturkan, sebab semakin banyak nama yang dia sebut dalam surat-suratnya. Dan ia kencan dengan beberapa pria sekaligus dalam kurun waktu yang sama. Aku agak bingung membacanya. Jika terlewat satu surat saja, cerita sudah melompat ke babak baru, seperti sinetron sabun. Apakah kamu tidur dengan semua? Tidak, jawabnya. Sebagian saja. Dalam sehari kamu bisa pacaran lebih dari satu orang? Iya, tapi tidak setiap hari. Bagaimana dengan orangtuamu yang dulu membuangmu ke pelosok Republik Indonesia supaya menjadi bermoral? Mereka tak bisa marah lagi, katanya. Malah, mereka kadang terpaksa melindungi aku dari pacar-pacar yang mengamuk karena kukhianati. (Utami, 2006: 152)

Dapat dilihat bahwa Cok adalah seorang perempuan yang mengadopsi kebebasan seksual. Dia digambarkan sebagai perempuan yang tidak peduli dengan aturan dan norma masyarakat. Aturan dan norma masyarakat tentang hubungan seksual diatur oleh laki-laki, karenanya menguntungkan laki-laki. Bahwa, tidur dengan sebagian dari pacar-pacarnya adalah hal yang biasa. Bahkan sejak masih di sekolah menengah pun dia sudah sering melakukan kegiatan seksual hingga menyebabkan dia dipindahkan sekolah karena tertangkap basah membawa alat kontrasepsi, kondom, di dalam tasnya. Seperti yang terdapat dalam percakapan di bawah ini: 
Akhirnya sepucuk surat datang dari Cok. Begini kutipannya: Tala yang baik,......Mama dan Papa menemukan kondom dalam tasku.....Aku cuma menulis surat ini pada kamu. Soalnya, Yasmin dan Laila bakal shock mendengar ini. Jangan-jangan nanti mereka tidak mau kenal lagi dengan aku (Utami, 2006: 151)

Kehidupan seksual Cok yang biasa berganti pasangan sangat dinikmatinya. Hal itu menunjukkan bagaimana dia dapat memainkan peranannya dalam permainan seksual yang biasa dilakukan laki-laki. Apa yang dilakukan Cok menunjukkan representasi seksual perempuan dalam posisinya berhubungan seksual. Dia menjadi subjek yang menikmati dan ikut menentukan permainan seksual.

\section{SIMPULAN}

Novel Saman karya Ayu Utami menampilkan representasi seksualitas perempuan. Keempat tokoh utama perempuan Laila, Shakuntala, Yasmin, dan Cok melakukan pendobrakan nilai-nilai yang ada dalam perkawinan. Lewat penggambaran kehidupan seksual keempat tokoh tersebut, Ayu Utami mempertanyakan aturan dan ikatan lembaga perkawinan dan posisi serta anggapan masyarakat tentang keperawanan. Pemberontakan yang dilakukan oleh keempat tokoh utama tersebut menunjukkan bahwa ideologi yang dibangun oleh sistem patriarkal telah menempatkan perempuan pada posisi lemah, tidak mempunyai kekuasaan, pasrah, dan menjadi objek seksual. Perempuan hanya dipandang sebagai benda yang tidak mempunyai perasaan dan jiwa serta dapat diatur sesuai keinginan laki-laki sebagai pemegang kekuasaan. Ideologi perempuan yang dibangun seperti tersebut di atas ditumbangkan oleh para tokoh utama perempuan dalam Saman dengan membuat representasi tandingan. Keempat tokoh utama perempuan dalam novel ini masing-masing mempunyai kesamaan pandangan tentang lembaga perkawinan dan identitas perempuan serta sikap terhadap hubungan seksual.

Keempat tokoh utama tersebut sangat menikmati kehidupan seksual mereka dan ikut aktif dalam hubungan ini serta menjadi subjek seksual. Mereka tidak melihat aturan yang diberlakukan dan dibuat oleh laki-laki sebagai penguasa; misalnya mereka berhubungan seksual dengan laki-laki yang terikat perkawinan, atau bahkan berhasil menarik perhatian dan melakukan hubungan seksual dengan seorang pastor yang namanya dipakai sebagai judul novel ini. Suatu kasus yang luar biasa terjadi bagaimana Ayu Utami menggambarkan dan menampilkan kehidupan seksual seorang perempuan dengan laki-laki yang “suci”. Hal ini menunjukkan pemutarbalikan ideologi kekuasaan laki-laki (yang biasanya menguasai) menjadi objek perempuan (yang biasanya dikuasai dan diatur)

\section{DAFTAR PUSTAKA}

Bandel, K. (2006). Sastra, Perempuan dan Seks. Jakarta: Gramedia.

Butler, J. (1990). Gender Trouble. New York: Routledge.

Childers, J., and Hentzi, G. (1995). The Columbia Dictionary of Modern Literary and Cultural Criticsm. New York: Columbia University Press.

Foster, E.M. (1970). Aspect of the Novel. London: Penguin Book.

Foucault, M. (1997). Seks dan Kekuasaan. Jakarta: Gramedia. 
Hall, S. (2003). Representation Cultural Representations and Signifying Practices. London: Sage Publications.

Kennedy, X. J. (2005). An Introduction to Fiction, Poetry and Drama. New York: Longman.

Maemunah. (2004). Relasi antara Wacana Seksualitas dan Kekuasaan: Analisis Struktural Dinamik pada Novel Saman dan Larung Karya Ayu Utami. Surabaya: Unair. Diakses dari http://digilib.unair.ac.id/go.php?id=jipunair-gdl-res-2004-maimunah-

12937node=238\&start=51\&PHPSESSID=f5f5739de6fbab8e4499a54b7b4b647d

Pamusuk, E. (1991). Novel dan Film. Yogyakarta: Nusa Indah.

Rathus, S. A., Nevid, J. S., Fichner, L. (2009). Human Sexuality in a World of Diversity. Boston: Pearson.

Ratna, N. K. (2007). Sastra dan Cultural Studies. Yogyakarta: Pustaka Pelajar.

Sambodja, A. (2005). Perempuan yang Mempersetankan Perkawinan. Diakses dari http://www.republika.co.id/koran detail.asp?id=214692\&kat id=364.

Semi, A. M. (1989). Kritik Sastra. Bandung: Angkasa.

Sugiarti. (2002). Tren Perjuangan Perempuan dalam Sastra Merangkul Tabu, Meretas Kekerasan Tersamar.

Diakses

dari http://www.sinarharapan.co.id/hiburan/budaya/2004/04/3/bud02.html.

Utami, A. (2006). Saman. Jakarta: Kepustakaan Populer Gramedia.

Wellek, R. (1995). Teori Kesusastraan. Jakarta: Gramedia. 